\title{
Genealogies as Tools: The Case of P and Chronicles
}

\section{Introduction}

The present paper explores the ways in which genealogies have been used by biblical authors who supported the Levites (in the sense of second-rank liturgical functionaries) over against the Aaronide and other priesthoods, constructed a unified Levi-Aaron-genealogy and at the same time emphasised the importance of the Zadokite Jerusalem priesthood. ${ }^{1}$ The paper does so against the background of research into the uses of genealogies conducted by social anthropologists. Research into biblical genealogies - or, for that matter, genealogies in any literature of the ancient world - can immensely benefit from insights won in social anthropology because the latter makes us aware of the social and political uses of genealogies, especially of their function in adopting narratives to changes in societal structures and political constellations. In non-literate societies, such processes of change are accompanied by adjustments to the existing genealogies, ${ }^{2}$ and in literate societies they are mirrored in the rewriting of genealogies in the extant authoritative texts: while writing leads to "the freezing of the genealogies", 3 this does not preclude the rearrangement of a written genealogy through rewriting it. This is, of course, particularly pertinent with regard to the uses of genealogies in Chronicles, in which written genealogies play a crucial role (1 Chr 4:33; 5:1, 7, 17; 7:5, 7, 9, 40; 9:1, 22; 2 Chr 12:15; 31:16-19; cf. Ezra 2:62; 8:1, 3; Neh 7:5, 64).

1 For my earlier work on the pre-history and history of the priests and Levites of Achaemenid Judah, cf. Joachim Schaper, Priester und Leviten im achämenidischen Juda: Studien zur Kult- und Sozialgeschichte Israels in persischer Zeit, FAT 31 (Tübingen: Mohr Siebeck, 2000).

2 See Jack Goody \& Ian Watt, “The Consequences of Literacy,” in Literacy in Traditional Societies, ed. Jack Goody (Cambridge: Cambridge University Press, 1968), 27-68 (= Comparative Studies in Society and History 5 [1963], 304-45), especially pp. 31-34, and Jack Goody, Myth, Ritual and the Oral (Cambridge: Cambridge University Press, 2010).

3 Jack Goody, The Logic of Writing and the Organisation of Society, Studies in Literacy, Family, Culture and the State (Cambridge: Cambridge University Press, 1986), 40.

Joachim Schaper, University of Aberdeen 
This essay is divided into three parts, devoted to (1) genealogies as explored by social anthropologists, (2) genealogies in $\mathrm{P}$ and Chronicles, and (3) the struggle for interpretative supremacy in Judah during the Achaemenid period.

\section{Genealogies and their functions from a social-anthropological perspective}

Kinship is one of the great and central themes of social anthropology, and genealogies are the key devices used by social groups for the purposes of social organisation and identity-formation. One might say that genealogies are tools because they are the instruments forged by a social group's key functionaries in order to establish, promote and perpetuate their view of the group's (supposed) kinship structure and because those genealogies, once they have been devised and established, can be used in the service of fighting those who resist that order and attempt to change it. This is one of the uses genealogies can be put to, and have been put to, in social and cultural confrontations throughout history.

But, of course, this is just one element of a complex picture. Social anthropologists have much more to say about the social and cultural functions of genealogies:

Eine Genealogie stellt ein Ordnungssystem dar, das auf die Frage nach der eigenen Herkunft ebenso antwortet wie auf die nach den verwandtschaftlichen Relationen innerhalb einer Gesellschaft. So manifestiert sich in der Genealogie eine Form der historischen Darstellung. Die genealogische Zuordnung, zum Beispiel in der einfachsten Form der Nennung des Vaters (und Großvaters), stellt eine Person in einen geschichtlichen Zusammenhang. Die Genealogie dient dabei jedoch nicht nur der Identifikation, sondern zugleich der Feststellung der Identität, insofern als sie Anteil hat an der Vorstellung, dass die Herkunft einer Person oder Sache etwas über ihr Wesen verrate. Die Herstellung der Identität durch den Aufweis der Abstammung korrespondiert der Wissensvermittlung vom Vater auf den Sohn usf. ebenso wie der Kongruenz von Gesellschaftsstruktur und Familienstruktur. ${ }^{4}$

Let us give some thought to what this might mean for our investigation of genealogies in the Hebrew Bible, and especially in the Priestly Writing and in Chronicles. In those genealogies, the relations between different groups of the priesthood are

4 This is the apt summary of social-anthropological approaches to genealogies, produced by a biblical scholar (Jürgen Ebach, "Genealogie," in Handbuch religionswissenschaftlicher Grundbegriffe, vol. II, ed. Hubert Cancik, Burkhard Gladigow \& Matthias Laubscher [Stuttgart, Berlin, Cologne: W. Kohlhammer, 1990], 486-49, here 486-87). 
expressed as relations of kinship. Thus, relations in society at a particular point in history are expressed as natural relations, as actual kinship relations. Social relations are thus invested with all the weight and significance of kinship relations. This is why the statement on the father-son succession in our quotation is so important: "Die Herstellung der Identität durch den Aufweis der Abstammung korrespondiert der Wissensvermittlung vom Vater auf den Sohn usf. ebenso wie der Kongruenz von Gesellschaftsstruktur und Familienstruktur.” In ancient Israel and Judah, as in most or all ancient societies, the priestly office and priestly education was handed on from father to son; there was a congruity between being the descendant of a man, being his pupil, and being his successor in office. Once again it is obvious how completely intertwined societal relations and kinship relations really were.

Also, and very importantly, genealogies are instruments that reflect, integrate, and make sense of change, while at the same time pretending that change has not taken place. Consider the following example adduced by Goody and Watt, an example taken from a non-literate society that was in transition towards being an at least partly literate one:

Early British administrators among the Tiv of Nigeria were aware of the great importance attached to these genealogies [which "stretch some twelve generations in depth back to an eponymous founding ancestor”, according to Goody; J.S.], which were continually discussed in court cases where the rights and duties of one man towards another were in dispute. Consequently, they took the trouble to write down the long lists of names and preserve them for posterity, so that future administrators might refer to them in giving judgement. Forty years later, when the Bohannans [Laura and Paul Bohannan, two social anthropologists; J.S.] carried out anthropological field work in the area, their successors were still using the same genealogies. However, these written pedigrees now gave rise to many disagreements; the Tiv maintained that they were incorrect, while the officials regarded them as statements of fact, as records of what had actually happened, and could not agree that the unlettered indigenes could be better informed about the past than their own literate predecessors. What neither party realized was that in any society of this kind changes take place which require a constant readjustment in the genealogies if they are to continue to carry out their function as mnemonics of social relationships. ${ }^{5}$

Genealogies as "mnemonics of social relationships" - this captures the essence of the problem. The Nigerian example was situated in the context of a non-literate society in which the changes in social relationships "require a constant readjustment in the genealogies”, but such readjustments remain imperceptible and

5 Goody \& Watt, "Literacy”, 32 
can, in the context of a non-literate society, hardly be traced and reconstructed. And if genealogies that only existed orally are, so to speak, brought to a standstill by being written down, they can no longer function as "mnemonics of social relationships" because they cannot be flexibly adjusted when the social relationships change. Conversely, in a literate society with its written genealogies, such written genealogies can also be continuously adjusted whenever social relationships change, but any such adjustment requires writing activities that result in modified records. Any literate person can then identify the difference between the original version and the modified one. In oral societies, such changes can be identified only by the functionaries who memorise the genealogies and modify them when they see fit.

In the case of the Tiv genealogies, the colonial administrators, who argued on the basis of the decades-old written records of the genealogies as they then presented themselves, did not understand the ways in which genealogies in non-literate societies evolve and therefore thought that they had fixed a precise account of kinship relations when they wrote down what they were being told by the "indigenes". The administrators did not understand that genealogies are malleable, ever-changing records - records indeed, but not "reliable" records in a modern Western sense, for the simple reason that they provide a snapshot of the current social relationships and are not intended to provide a record of actual kinship relations in a distant past. Instead, they construct supposed kinship relations that mirror the actually existing social structure in order to achieve social and political objectives.

While genealogies are particularly malleable in non-literate societies, they can be handled very flexibly even in societies where the practice of writing is well established among the elites and where therefore written genealogies are, at least in principle, open to public scrutiny. The development of priestly genealogies in the Hebrew Bible is a case in point. The modifications introduced in Chronicles to genealogies already found in $\mathrm{P}$ were introduced not least because of the political need to confer authority upon a temple hierarchy that had evolved over time and needed to reaffirm its claim to authority. We shall explore this in some detail in the next section.

It must be kept in mind that it is one of the many features of genealogies to regulate access to privilege by defining the group deserving of privilege by means of constructing kinship relations. The Hebrew Bible is full of examples of that function of genealogies; a particularly salient one is found in Ezra 2:62-63//Nehemiah 7:64-65 where those who want to have their supposed priestly status confirmed

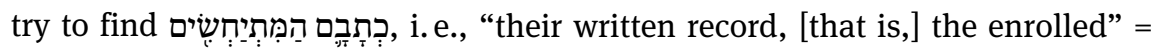
"their written genealogy". Such a written genealogy determined whether or not certain persons could be considered legitimate priests and therefore be admitted 


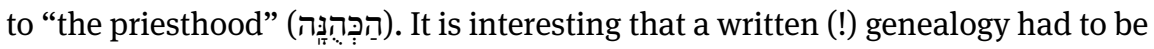
submitted in order to be given access - references to oral traditions were obviously not considered sufficient.

\section{Genealogies in P and Chronicles}

In the Hebrew Bible, and especially in $\mathrm{P}$ and Chronicles, genealogies play a significant role, and in Chronicles (as well as in Ezra-Nehemiah) written genealogies have a very special place. ${ }^{6}$ The genealogies in Chronicles, to which I shall give special attention, are a particularly complex and salient attempt to use what is passed off as a record of the past as a mirror of the present and a foundation for the future. They have to be seen in the wider context of what David N. Freedman has called "the Chronicler's purpose", stating that

[...] the Chronicler establishes through his narrative of the reigns of David and Solomon the proper, legitimate pattern of institutions and their personnel for the people of God; and they are the monarchy represented by David and his house, the priesthood, by Zadok and his descendants, the city and the temple in the promised land. City and ruler, temple and priest - these appear to be the fixed points around which the Chronicler constructs his history and his theology. ${ }^{7}$

Freedman makes a persuasive case for his understanding of the Chronicler's purpose and for seeing the significance of the Davidic monarchy as the key to the interpretation of his work. We shall return to this observation later, in the conclusion to this essay.

The genealogies that are of interest to us here were originally devised in writing (possible "forerunners" in the shape and form of orally-transmitted gene-

\footnotetext{
6 On biblical genealogies generally, cf. especially Robert R. Wilson, “The Old Testament Genealogies in Recent Research," JBL 94 (1975): 169-89 and Robert R. Wilson, Genealogy and History in the Biblical World (New Haven, Conn: Yale University Press, 1977). On the priestly and Levitical genealogies in Chronicles (1 Chronicles 5:27-6:38) and their societal and ideological purposes, cf., among others, Antti Laato, "The Levitical Genealogies in 1 Chronicles 5-6 and the Formation of Levitical Ideology in Post-Exilic Judah,” JSOT 62 (1994): 77-99. Laato insightfully differentiates between "historical genealogy" and "ideological genealogy" (p. 77) and demonstrates some of the purposes which the genealogies of Chronicles were intended to serve.

7 David N. Freedman, “The Chronicler's Purpose,” CBQ 23 (1961): 436-42, here 437-38. On Chronicles and possible attempts at a restoration of the Davidic monarchy in the fourth century, see David Janzen, Chronicles and the Politics of Davidic Restoration. A Quiet Revolution, LHBOTS 655 (London: Bloomsbury T\&T Clark, 2017).
} 
alogies are impossible to reconstruct), and they are different from genealogies devised in non-literate societies because they do not suffer the problem of "genealogical shrinkage". ${ }^{8}$ What both written and oral genealogies have in common, though, is that they are "governed by the concerns of the present". 9

With regard to the use of priestly genealogies in Chronicles and the relation between them and priestly genealogies in $\mathrm{P}$, the exemplary text, where all the key characteristics of the use of such genealogies converge, is found in 1 Chronicles 5:27-6:38 [English 6:1-53]:

Gary N. Knoppers comments:

By situating the descendants of Zadoq within a broader genealogical context, the author avoids developing antitheses between priests and Levites, Aaronides and Zadoqites, Eleazarides and Ithamarides. The writer negotiates among established positions and synthesizes disparate traditions. In Chronicles the Aaronides are, broadly speaking, Levites (1 Chr 5:27). To some extent, the Levitical genealogies relativize the distinction between priests and Levites by speaking of Qohathites, Merarites, and Gershonites. Within these large phratries there can be specializations. Some Qohathites are priests (5:27-41), while other Qohathites are singers (6:7-13,18-23). The Qohatite priests clearly have a privileged position. But the Merarites, Qohathites, and Gershonites who function as singers (6:5-33) can lay claim to the same impeccable roots (6:1-4) as the Qohathite priests (5:27-29). All are Levites, who share a common genealogy. Some biblical and postbiblical authors draw clear contrasts among sacerdotal groups, but in Chronicles they all are ultimately part of the same organization. ${ }^{10}$

8 Goody \& Watt, “Literacy”, 32: “[...] consequently the added depth of lineages caused by new births needs to be accompanied by a process of genealogical shrinkage; the occurrence of this telescoping process, a common example of the general social phenomenon which J. A. Barnes has felicitously termed 'structural amnesia', has been attested in many societies".

9 Contra Goody \& Watt, "Literacy", 34, where they write of the genealogies of the Tiv and others: "But all their conceptualizations of the past cannot help being governed by the concerns of the present, merely because there is no body of chronologically ordered statements to which reference can be made. The Tiv do not recognise any contradiction between what they say now and what they said fifty years ago, since no enduring records exist for them to set beside their present views. Myth and history merge into one: the elements in the cultural heritage which cease to have a contemporary relevance tend to be soon forgotten or transformed; and as the individuals of each generation acquire their vocabulary, their genealogies, and their myths, they are unaware that various words, proper names and stories have dropped out, or that others have changed their meanings or been replaced." Rather, it seems that both oral and written genealogies, while they are differently situated, need to respond to "the concerns of the present". The Levi-Aaron-genealogy is a perfect example of that.

10 Gary N. Knoppers, I Chronicles 1-9: A New Translation with Introduction and Commentary, AB 12A (New York: Doubleday 2003), 415. 
In a previous publication, I drew attention to these same facts and pointed out that this genealogical arrangement is the expression of the desire to consolidate and stabilise the temple hierarchy by promoting the new "inclusive" view by means of the ingenious construct that is the Levitical genealogy placed in what Rothstein called the "genealogische Vorhalle". ${ }^{11}$ In the text quoted above, Knoppers makes a similar point, and it is indeed true that Chronicles devises a genealogy that accommodates diverse priestly families under one imaginary umbrella, that of the postulated lineage of Aaron who is seen as a descendant of Levi; even and especially Zadok is integrated into this lineage. ${ }^{12}$ The Chronicler's construct thus accommodates just about everyone on the priestly side who can be accommodated. In that sense it "synthesizes disparate traditions", and in doing so it regulates access to the privilege of being considered a legitimate priest: where there is no written genealogy (Ezra 2:62-64//Nehemiah 7:61-65), someone's priestly status cannot be ascertained and the person is precluded from priestly privilege (Ezra 2:62!); conversely, where such a written genealogy confirming someone's priestly status exists, that person is accepted as being a legitimate priest.

But there is another way of looking at the passages Knoppers adduces. While the author of the genealogy "avoids developing antitheses between priests and Levites, Aaronides and Zadoqites, Eleazarides and Ithamarides”, he subsumes the priests, together with the Levites (in the sense of second-rank cultic officials), under the same eponymous ancestor Levi. This leads to the result that, indeed, "the Levitical genealogies relativize the distinction between priests and Levites by speaking of Qohathites, Merarites, and Gershonites”. At the same time - and that is the point - they subtly subvert the distinction altogether. More than that:

11 Schaper, Priester und Leviten, 304-5.

12 Alice Hunt, Missing Priests: The Zadokites in Tradition and History, LHBOTS 452 (New York/ London: T \& T Clark, 2006) and Nathan MacDonald, Priestly Rule: Polemic and Biblical Interpretation in Ezekiel 44, BZAW 476 (Boston, MA: De Gruyter, 2015) both question, in different ways, the existence of a historical priesthood of Zadokites. There are many observations that contradict such views of the Zadokite priesthood. I shall just mention one. The elusiveness of the figure of Zadok in the biblical texts is often adduced to give a basis to 'minimalist' views of the history of the pre-exilic Zadokite priesthood. But while the eponymous ancestor of that priesthood may well not have been a historical character, the fact that the concept of a Zadokite priesthood plays such a distinct role in the Hebrew Bible indicates that a priesthood claiming descendance from what may well be an ahistorical figure of that name actually existed historically, just like - to name just one example - the famous Roman noble family, the gens Iulia, which claimed to be descended from the mythical figure Iulus, the son of Aeneas. On the question of the historicity of a Zadokite priesthood, cf. also Lars Maskow, Tora in der Chronik: Studien zur Rezeption des Pentateuchs in den Chronikbüchern, FRLANT 274 (Göttingen: Vandenhoeck \& Ruprecht, 2019), 322-33. 
the genealogies integrate the priests so fully under the general heading of the descendants of Levi that it becomes easier and easier completely to ignore the distinction between priests and second-rank functionaries, i.e., Levites. ${ }^{13}$

But that is still not the full picture. There are tensions within Chronicles with regard to the question of the priests' status and their historical, dynastic and theological significance vis-à-vis the status and significance of the Levites. The whole problem comes together in 1 Chronicles 5:27-6:38. At the tail end of this, in 1 Chronicles 6:35-38 [English 6:49-53], we have a reiteration of what one might call the backbone of the priestly genealogy in chapter 5:27-41 (i.e., 5:29-34): the segment of the high-priestly genealogy that runs from Aaron to Zadok and his son, i.e. that part of the genealogy which integrates the Zadokite priesthood into the "Levi"-construct and thus constructs a line that artificially unifies historically separate Judahite priesthoods. In so doing, it uses the Levi-Aaron-genealogy of $\mathrm{P}$ in Exodus 6:14-25 to great effect as a basis for the genealogical adjustment in 1 Chronicles 5:27-41. ${ }^{14}$

Why is the key segment of the high-priestly genealogy of 5:27-41 found again here in 1 Chronicles 6:35-38? Why would the Chronicler, in a strategically crucial place of his work, wish to stress the importance of certain segments of the priesthood (as opposed to the Levites), and especially of Zadok (and thus of the Zadokite priestly tradition)? Interestingly, it has been postulated that 1 Chronicles 6:35-38 is a later addition. ${ }^{15} \mathrm{Be}$ that as it may, the crucial point is that the passage is part of the final form of Chronicles and is supposed to make sense in that context.

On the one hand, placing 1 Chron. 6:35-38 in the overall context of 1 Chronicles 5:27-6:38 may simply indicate that Chronicles pays lip-service to the priesthood while at the same time submerging it in a sea of general "Levitical" respectability. In any case, it is part of the process of redefining what is considered to be the legitimate priesthood, a process that was intended to change the regulation

13 Schaper, Priester und Leviten, 269-302.

14 Schaper, Priester und Leviten, 35-36, 269-79.

15 On the relationship between 1 Chronicles 5:27-41 and 6:35-38, cf., amongst others, Sara Japhet, 1 Chronik, HTKAT (Freiburg: Herder, 2002), 167. (This is the updated German translation of the English version of Japhet's commentary.) It should be noted that the majority of Chronicles scholars see the shorter genealogy as the earlier and the genealogy in 5:27-41 as the younger one; cf., amongst many others, Martin Noth, The Chronicler's History, trans. Hugh G. M. Williamson, JSOTS 50 (Sheffield: Sheffield Academic Press, 1987), 39-40. Knoppers and others take the opposite view; see Gary N. Knoppers, "The Relationship of the Priestly Genealogies to the History of the High Priesthood in Jerusalem," in Judah and the Judeans in the Neo-Babylonian Period, ed. Oded Lipschits and Joseph Blenkinsopp (Winona Lake: Eisenbrauns, 2003), 109-34, here 116-122, and Ralph W. Klein, 1 Chronicles (Minneapolis: Fortress Press, 2006), 176. 
of access to the central instrument of power in the Achaemenid period (in the absence of kingship in Judah): the temple hierarchy. ${ }^{16}$

But what is the crucial point about integrating Zadok into the Levi-Aaron-genealogy in 1 Chronicles 5:27-41 and then repeating that section of the genealogy in 1 Chronicles 6:35-38? Was that done simply with the aim of legitimising the Zadokite line, ${ }^{17}$ or was there another, more complex reason for this construct? The Zadokite line did not really need to be "legitimised" (it commanded respect because of its significance in the history of the Jerusalem cult), but - from the perspective of the Chronicler - it needed to be fully integrated into the comprehensive construct of his Levi-Aaron-genealogy, in order for that genealogy to stabilise and perpetuate the new equilibrium of the cultic hierarchy and the liturgical practice of the Jerusalem cult that was emerging in the late Persian period. 1 Chronicles 5:27-41 and 1 Chronicles 6:35-38 thus served the purpose of integrating the Zadokite line. ${ }^{18}$

But there is another, more subtle element to the integration of Zadok into the Levi-Aaron-genealogy. A key intention behind this strong emphasis on Zadok is to stress the importance of the sacerdotal service rendered by the Zadokite priests in the Davidic and Solomonic ages, to claim normative status for their way of conducting the divine service, and to construe the Davidic and Solomonic periods as a "golden age" of the cult. This was part of the larger objective identified by Freedman in his foundational essay. ${ }^{19}$ While it is true that extolling the Davidic age was by no means the sole objective of the Chronicler (as Sara Japhet has pointed out), ${ }^{20}$

16 I have described the way in which this was accomplished in Schaper, Priester und Leviten, 269-302.

17 This is assumed by Maskow, Tora, 257, who seems to see this as the only reason for integrating Zadok into the genealogy: "Hinter der Liste steckt also die Absicht, der zadokidischen Linie priesterliche Legitimation zu verschaffen, indem sie in den Aaron-Stammbaum eingeschrieben wird. Es liegt demnach keine reale Abbildung von Abstammungsverhältnissen, sondern das Durchsetzungsmittel eines Herrschaftsdiskurses vor." That "keine reale Abbildung von Abstammungsverhältnissen" is attested, is not surprising at all; see the discussion above on the typical functions of genealogies that are found in social-anthropological studies in a range of societies.

18 Given the space constraints, we cannot revisit here in detail the complex scholarly discussion of the function of the genealogies in the history of the exilic and post-exilic recalibration effecting the relations between the priestly families of Judah - families that had entertained complex relations in the pre-exilic period. For a recent in-depth review of that scholarly discussion, focusing on the genealogies in Chronicles, cf. Maskow, Tora, 240-333.

19 See above, note 6.

20 See Japhet, 1 Chronik, 75-77 in the context of the discussion of the theological tenets of Chronicles, 72-78. 
it is equally true that the Chronicler saw that age as the defining golden age of all "Israel". Most importantly, the temple service is at the heart of hearts of "Israel" in the Chronicler's sense, as we shall see in more detail later.

\section{The struggle for interpretative supremacy in the Achaemenid period}

What I have drawn attention to in Chronicles (amongst other things, like the concept of the importance of the liturgical activity of the Zadokite priests in Davidic and Solomonic times), is the fact that the Levi-Aaron-genealogy subsumes the priests under the general heading of the descendants of Levi so that it becomes possible completely to ignore the distinction between priests and second-rank functionaries, i. e., Levites. This is an interpretative strategy intended by the authors of Chronicles to subvert the position of another group of temple functionaries in Judah in the Achaemenid period, i.e., that of priests opposed to the endeavour of the Levitical circles represented by the Chronicler. That priestly position is exemplified by the Korach episode in the book of Numbers which bears the traces of priestly resistance to the cause of the Levites. Jaeyoung Jeon writes in a recent article:

Korach is not a well-known figure in the Pentateuch, appearing only in late redactional passages (e. g., Exod. 6.21,24; Num. 26.9; 27.3). In Chronicles, however, Korach is described as an ancestor of several influential Levitical clans responsible for the three main tasks of the Levites: singing, gatekeeping and ancillary temple service (1Chron. 9.19, 31; 26,1, 19; 2 Chron. 20.19). Probably in consideration of such Levitical genealogy, the priestly (most likely Zadokite) scribe chose Korach as the main antagonist representing the Levites. ${ }^{21}$

And as I pointed out elsewhere, ${ }^{22}$ the Korach episode in Numbers 16 is indeed an instance of the struggle of (segments of) the priesthood against the emancipatory efforts of the Levites. The Levites' efforts to level the distinctions within the priesthood were seen, by some priests, as being potentially detrimental to their position and function within the temple system and the society of Yehud in general. The

21 Jaeyoung Jeon, “The Zadokite and Levite Scribal Conflicts and Hegemonic Struggles," in Scripture as Social Discourse: Social-Scientific Perspectives on Early Jewish and Christian Writings, ed. Jessica M. Keady, Todd E. Klutz \& C. A. Strine (London: Bloomsbury Academic, 2017), 97-110, here 103.

22 Schaper, Priester und Leviten, 298-300. 
use of the figure of Korach serves to denounce the Levitical efforts at subversion. It is intended to delegitimise the Levites, and the fact that references to Korach show up only in late passages unsurprisingly locates that struggle between priests and Levites in the late Achaemenid period, i. e., the period in which, for a number of reasons, we have come to expect the confrontation between priests and Levites to have taken place.

Let us now make an attempt to understand more precisely the nature of the confrontation between the Levites and the supposedly "Levitical" priests. What did the Levites, represented by the Chronicler, really attempt to achieve? How can we conceptualise the nature of their endeavour? Recently, Jeon has applied Gramsci's notion of cultural hegemony to the interpretation of the situation between the priests and Levites in the late Achaemenid period. Can the Levites' endeavour really be described as a struggle for cultural hegemony? While the confrontation between the priests and the Levites in that period was indeed a power struggle conducted with the intellectual weaponry available to priests and scribes, and in that sense a cultural struggle, I would describe it as a struggle for interpretative supremacy, not as a struggle for cultural hegemony in Gramsci's sense. Gramsci's notion of cultural hegemony was developed under the conditions of the 1920s and '30s and is informed by the political struggles in Italy and elsewhere in Western and Central Europe in that period. It made perfect sense in that context and still makes sense today, especially with regard to the losing battle the Left seems to be fighting, in many European countries and in the USA, against the encroachment of the Right on the political, legal and cultural institutions of those countries. However, a struggle for cultural hegemony in Gramsci's sense can only take place under the conditions of modern capitalist class-societies, focussing on the cultural apparatuses commanded by the ruling classes. It is with the help of these apparatuses that the struggle for hegemony is conducted.

Gramsci's notion cannot be applied to pre-capitalist societies, let alone to ancient ones. Yet one may concede that Gramsci's concept can be used heuristically, in the following sense: the struggle between the priests and the Levites was conducted - not exclusively, but to a significant degree - by means of the tools of the intellectual: the alphabet, the stylus, and the intellectual construct. While it cannot be understood as a struggle for cultural hegemony in Gramsci's sense, it is an attempt by one group of the temple personnel subtly to subvert the power of another. It is an important attempt at subversion because it concerns the power balance in the most important institution of Yehud's society, its one remaining temple - a temple that was, like other temples in the Near East and elsewhere, not just a religious but also a financial and administrative centre.

The attempted result of the subversion was a levelling of the internal hierarchy of the Jerusalem temple: not a complete levelling, as the internal differen- 
tiation of the hierarchy and the special interest in the Aaronic line and in Zadok demonstrate. This levelling was the expression of - or laid the basis for; that is hard to tell - a more egalitarian approach to the rights and duties of religious functionaries which started to emerge in the late Achaemenid period. It is the beginning of what I have elsewhere dubbed the "Levitical-Pharisaic tradition," i.e., the tradition of scriptural exegesis ultimately rooted in the work of Levites in the late Persian period, taken up and developed by the earliest Pharisees, and fully established by Pharisaism in the Hellenistic and Roman periods. ${ }^{23}$ The members of that movement - and of its later permutation, the early rabbinic tradition - did not have an entirely hostile attitude towards the priesthood, but they were wary of the priests, and they did not like the priesthood to become too powerful. What they therefore tried to do was to channel the available religious energy not exclusively through the ritual sacrifices offered by the priests but also through liturgical and textual practices. Their intellectual tool of choice in that process was the genealogy. While the elite of Yehud was literate, and while, therefore, the manipulation of genealogies was in principle open to scrutiny, the people behind Chronicles nevertheless chose written genealogies to make their point. As we have seen, the ways in which they manipulated the material were quite subtle; they made seemingly minor changes, re-emphasising some of the aspects of the existing material and integrating lineages into contexts from which they had been missing, as in the case of 1 Chronicles 5:27-41 and 1 Chronicles 6:35-38, which build on Exodus 6:14-25. While there are obvious problems with the manipulation of genealogies in a society that is largely literate, the people behind Chronicles nevertheless went in for such manipulation. They executed their self-chosen task subtly and efficiently; the fact that they instrumentalised genealogies, in spite of the obvious problems, is due to the fact that genealogies continued to be key instruments of legitimisation.

The Levites started out on a transformation of the cultic practices of the Yahweh religion which ultimately ensured that it could survive without a sacrificial cult. To make do completely without a sacrificial cult had of course never been the intention, but when that point was reached much later, religious survival had become possible because the sacrificial cult had been supplemented with textual and liturgical practices which ultimately proved to be able to supplant it. The importance of the divine service was stressed by affording genealogical "room" to Zadok and his descendants, the practitioners of the temple service

23 Cf. Schaper, Priester und Leviten, 307 and Joachim Schaper, “The Pharisees," in The Cambridge History of Judaism, vol. 3: The Early Roman Period, ed. William Horbury, William D. Davies and John Sturdy (Cambridge: Cambridge University Press, 1999), 402-27. 
of the Davidic and Salomonic ages as seen by the Chronicler, that is, the form of service considered normative by the Chronicler. Without the subtle Levitical reform and the textual strategies employed to bring it about, aimed as they were at countering the preponderance of the priesthood and at making use of priestly traditions (like that of the Zadokites) where it suited the Levites, ${ }^{24}$ that religious and cultural survival would not have been possible.

Let us now return to the observation that the Chronicler's work is focused on the Davidic monarchy and its importance in the context of the 'restoration' - or rather: reinvention - of Judah after the exile. If we look at the whole of 1 Chronicles 5:27-6:38, it is clear that the genealogical manipulations that were used to construct it betray the desire to unify hitherto divergent priestly traditions. What also emerges is the wish to let the 'actually existing' Yahweh temple hierarchy of Yehud bask in the light of the imagined priesthood of the past (an imagined priesthood in which the difference in authority between priests, Levites and other cult functionaries was blurred or even dissolved), and to do that in the service of the nostalgia for a Davidic empire that was never going to return. In that nostalgic projection, the "Levitical" singers (who are classified as being descended from Gershon, Qohath and Merari) were given the central task of performing the temple liturgy (1 Chr 6:16-18). The importance of the cult in the system created by the Chronicler is also demonstrated by the fact that the "tribe" of Levi receives the greatest amount of attention of all the tribes in the "genealogische Vorhalle" of 1 Chronicles.

By devising the genealogical construct of a system of cult functionaries descended from Levi that integrated both the Aaronides and the Zadokites and undermined the traditional strict hierarchy between "castes" of temple functionaries, and by also emphatically stressing the historic role of the Zadokites as the functionaries of the normative cult, three things were achieved: (1) a maximum of integration was accomplished, in the sense that historically separate and competing priestly traditions (i.e., traditions that had historically laid claims to priestly authority in pre-exilic Judah) were accommodated under one (imaginary) roof; this integration constituted (2) the basis for a peaceful coexistence of the descendants of the various priestly families; and (3) the integration of the Zadokites enabled the Chronicler further to underline the achievements of the

24 Cf., from another perspective, Benjamin Giffone, "Atonement, Sacred Space and Ritual Time: The Chronicler as Reader of Priestly Pentateuchal Narrative" (in the present volume): "As an early interpreter of Torah, he [the Chronicler; J.S.] seems to be charting a path that is inclusive of both Deuteronomistic and Priestly traditions (understood broadly), and of both Levites and Zadoqite priests in their specific, necessary roles. The Chronicler's circle and the Jerusalem cult's sphere of influence was too small to be exclusive." 
Davidic monarchy by stressing the historic importance and the continuing normativity of the divine service at the Jerusalem temple as conducted by the Zadokites in the Davidic and Solomonic ages..$^{25}$

It has recently rightly been stressed that it is important to "consider[] not just the parallel, but also the new passages in Chronicles that assign greater space, attention, and weight to the altar as compared to the books of Samuel and Kings mainly in relation to the establishment of the temple [...]", with "the altar" referring to "the outer, burnt-offerings sacrificial altar, not the incense altar". ${ }^{26}$ Itamar Kislev's research is not based on the priestly/Levitical genealogies of Chronicles but effectively confirms my conclusion (3), which I have derived entirely from an analysis of the relevant genealogies, by presenting a compelling argument which is derived from the analysis of Chronicles passages that are without parallel in Samuel and King: "Significantly, all these references to the altar are chronistic additions in relation to the accounts in Samuel and Kings; as new additions, they reflect the Chronicler's view of the enhanced importance of the altar."27 The "enhanced importance of the altar" propagated by the Chronicler represents a new, strong emphasis on the importance of the Jerusalem sacrificial cult as conducted by the Zadokites - an idealised view of the cultic history of the temple intended to serve as a norm for the present, for the cultic life of the Jerusalem temple in the fourth century. But the Chronicler's endeavour was not just to stress the importance of the altar, and of the sacrifice as such, but he also intended to stress the importance of the liturgy (and, importantly, of the liturgical music) that accompanied it: Kislev stresses, with regard to 2 Chronicles 5:11-13, that "[t]he reader may rightly understand that the appearance of the cloud and the glory of YHWH were not a consequence of the bringing of the ark into the temple, but of the priestly and Levitical ceremonial performance of music." ${ }^{28}$ Here again, an analysis based on new materials in Chronicles leads to the same conclusion as

25 This sprang from the growing refinement of the cult and the heightened interest in liturgical music that becomes obvious from numerous passages in 1 and 2 Chronicles, cf. Schaper, Priester und Leviten, 280-90, especially 282-84. On the importance of the cult, now see Itamar Kislev, "The Role of the Altar in the Book of Chronicles", JHS (2020), article 3. On ritual and atonement in Chronicles, cf. Giffone, "Atonement, Sacred Space and Ritual Time," in the present volume.

26 Kislev, "Role," 5.

27 Kislev, "Role," 8: "By twice describing the sanctification of the location of the temple through the descent of fire on the altar and the divine election of this site, the Chronicler underscores the centrality of the altar in the temple's array. He reinforces this theme through the mention of the altar in David's declaration as well (1 Chr 22:1)."

28 Kislev, "Role," 5: "Whereas in Kings the filling of the house with the glory of YHWH is clearly a direct result of the bringing of the ark into the temple, in the chronistic account the sequence of events is less clear. The reader may rightly understand that the appearance of the cloud and 
an analysis focused on the Chronicler's genealogies: in Chronicles, there is a new, emphatic stress on the temple liturgy.

It must remain open whether this stress on the sacrificial cult and the liturgy was part of a concrete programme of Davidic restoration in the late Persian period, ${ }^{29}$ but that certainly is an aspect worth exploring. The sacrificial cult and the liturgy that accompanied it (according to the Chronicler's view of the history of the cult) were thus set up as the perennial ideal of worship, as the perfect divine service which ensured the favour of Yahweh and in so doing guaranteed the efficacy of Israel's interactions with the deity.

\section{Conclusion}

In the present essay, I have attempted to demonstrate how an approach to the Chronicler's genealogies that is inspired by social-anthropological research can help us to understand more deeply how genealogies were devised as tools to be operated in a discourse about priestly and Levitical legitimacy and the function and organisation of the temple cult in the late Achaemenid period. I have also shown that the results thus won, by focusing on the genealogies in Chronicles, are interestingly confirmed by research conducted from a very different perspective, i.e., research that concentrates on those 'cultic' passages in Chronicles that are not derived from Samuel and Kings but come from the Chronicler's own hand. Independently of each other, both approaches arrive at the conclusion that the sacrificial cult and the liturgy celebrated at the temple are of crucial importance to the Chronicler's concept of what defines 'Israel', to his view of the history of the Israelite priesthoods, and to his view of the present relations between the priests and Levites and their task in the enterprise of the reinvention of 'Israel' under foreign domination.

the glory of YHWH were not a consequence of the bringing of the ark into the temple, but of the priestly and Levitical ceremonial performance of music."

29 Cf. the historical reconstruction attempted by Janzen, Chronicles (see above, n. 7). 